\title{
COGNITIVE AND PSYCHOLINGUISTIC NATURE OF METAPHOR AS A BASIS OF AUTHOR'S CONCEPTUAL SYSTEM IN POETRY
}

\section{Chendey N. V.}

\section{INTRODUCTION}

In modern linguistics the conceptual methodology and procedures of poetic language study are elaborated by a separate branch of poetics cognitive, whose scientific vector is aimed at the analysis of artistic semantics with a special emphasis on linguistic and cognitive strategies of forming and processing information, which is actualized in poetic texts ${ }^{1}$. The principle of embodied understanding proves to be fundamental and it bases the analogy mapping as a mechanism of conceptual metaphor and metonymy formation ${ }^{2}$. Thus, in the theory of cognitive poetics a special focus is put on a problem of language metaphorization that involves not only the stylistic tropes, but embraces the whole process of nomination and sense organization in poetry, defining the peculiarities of the conceptual system of its author.

The study of conceptual metaphors in literary texts enables to reveal not only the specificity of verbal poetic images formation, but the explication of a conceptual content of a literary text and on this basis further define the principles of author's cognitive style ${ }^{3}$. The analysis of recent research on poetry confirms that cognitive poetics studies different stages of an artistic text functioning cycle: the author (an individual

1 Воробйова О. П. Когнітивна поетика : здобутки i перспективи / О. П. Воробйова // Вісник ХНУ ім. В.Н.ККаразіна. Ювілейний збірник "200-річчя Харківської мовознавчої школи”. Харків : Константа, 2004. № 635. С. 18-22.

${ }^{2}$ Freeman M. Poetry and the Scope of Metaphor : Toward a Cognitive Theory of Literature / M. Freeman // Metaphor and Metonymy at the Crossroad: A Cognitive Perspective / Ed. Barcelona A. Berlin ; N.Y. : Mouton de Gruyter, 2000. P. 253.

${ }^{3}$ Freeman M. The Body in the World: A Cognitive Approach to the Shape of a Poetic Text / M. Freeman // Cognitive Stylistics : Language and Cognition in Text Analysis / Ed. by E. Semino, J.V. Culpeper. Amsterdam ; Philadelphia : John Benjamin's Publishing House, 2002. P. 24. 
concept sphere) - the artistic reality (a conceptual text structure) - the reader (cognitive mechanisms of perception) as well as the interconnection between all of them. In particular, R. Tsur, one of the proponents of cognitive poetics, considers its primary tasks to be the study of cognitive mechanisms of perception and systematization of psychological affects, provoked by poetry and tightly connected with the specificity of text organization ${ }^{4}$. The issue of individual conceptual sphere as a mental basis of the author's poetic style remains open due to the complexity of its structure and compulsory components typology. In this research the attempt has been made to model an individual conceptual system of the author by studying poetic metaphors, their cognitive and psychological nature in order to define the features of the poet's individual style.

\section{Cognitive and psycholinguistic aspects of metaphor}

Metaphorization is one of the distinguishing features of the artistic perception of reality. These are metaphors in a poetic text that make it possible to transform animate and inanimate phenomena into abstract allegories. Being personified in metaphors they turn into spiritual creatures, making poetry alive. Moreover, a metaphor can be easily interwoven in dense canvas of a poetic text, designing the structure of complex verbal poetic images that successfully combine abstract and subject-concrete, preserving their inner symbolic content. And it is romantic poetry that proves to be the source of concentration "the secrets of soul", and its language is a code, deciphering which a reader penetrates into an emotional world of a poetic hero, touching upon his/her mysterious passions and multiple associations.

Cognitive linguistics gives metaphor a key position in structuring and understanding reality, reflecting cultural traditions of selecting modes of abstract concepts verbalization, conditioned by various extralinguistic factors (background knowledge about the world) typical of a given

\footnotetext{
${ }^{4}$ Tsur R. Toward a Theory of Cognitive Poetics / R. Tsur. Amsterdam: Elsevier Science Publishers, 1992. P. 14.

5 Павличко С.Д. Байрон. Нарис життя і творчості / Соломія Дмитрівна Павличко // Зарубіжна література : Дослідження та критичні статті. К. : Вид-во Соломії Павличко “Основи”, 2001. С. 153.
} 
language community ${ }^{6}$. One of the theoretical postulates of cognitive studies is an assumption that metaphor is a principle of thinking that provokes a semantic process of "subjecting" non-subject entities (psychological, mental, emotional) and their conceptualization by analogy with the subject world ${ }^{7}$. Correspondingly, the key function of metaphor seems to be its capacity to give an access to understanding abstract spheres of human experience. In G. Lakoff's opinion, a language system itself enables the conceptualization of invisible worlds, which become similar to visible ones for their verbalization and comprehension. A metaphor provides an understanding of experience and allows the perception of its distant fragments that lack their own pre-conceptual structure. G. Lakoff calls the ability to think metaphorically "a real triumph of human mind". The scholar considers metaphor to be a main tool of thinking, as far as any attempt to describe it should contain mechanisms of imagination and the latter is inseparable from metaphorical thinking. Metaphor is inbuilt in a human notional system and guides the human activities in the process of perceiving the reality since metaphor contains knowledge about the world.

A blended psychological and linguistic study of metaphor displays two planes of this complex phenomenon: 1) a content plane which reveals the psychological processes of reality elaboration; and 2) an expression plane that demonstrates a linguistic relation between the components serving in language as the evidence of these psychological processes.

Apprehension and perception have always been tightly linked in classic theories of metaphor. In P. Ricoeur's opinion, both of them are natural components of the process described in the metaphor theory as "an interaction" and represented in a semantic plane of metaphor". Being accompanied and extended by apprehension, perception is called a

${ }^{6}$ Арутюнова Н. Д. Метафора и дискурс / Н. Д. Арутюнова ; [пер. с анг., фр., нем., исп., польск. яз., общ. ред. Н. Д. Арутюновой и М. А. Журинской] // Теория метафоры : сборник. М. : Прогресс, 1990. С. 5.

${ }^{7}$ Lacoff G., Johnson M. Metaphors We Live By / G. Lacoff, M. Johnson. Chicago : The University of Chicago Press, 1980. P. 75.

${ }^{8}$ Lacoff G., Johnson M. Metaphors We Live By / G. Lacoff, M. Johnson. Chicago : The University of Chicago Press, 1980. P. 82.

${ }^{9}$ Рикёр П. Метафорический процесс как познание, воображение и ощущение / П. Рикер ; [пер. с анг., фр., нем., исп., польск. яз., общ. ред. Н. Д. Арутюновой и М. А. Журинской] // Теория метафоры : сборник. М. : Прогресс, 1990. С. 429. 
"mood". Thus, any poem structures a mood which emerges in the result of chaining a range of words. A mood is a means by which a poem has an impact on us, being an iconic sign. In the line with this, the philosopher states that "the unity of poetic language is the unity of mood" and metaphoric images express or interpret this mood, which is "a poetic language and nothing beyond it", "mood is iconic as it is felt",

Being an inseparable component of apprehension, a metaphoric sense is revealed in a verbal structure of poetic language. The psycholinguistic approach to a metaphor study puts to the fore its sensual aspect that is brilliantly displayed in poetry. It creates a breeding ground for an amalgamation of sense and perception, a sensual world vision that distinguishes a poetic language from non-poetic, in which sense is totally purified from a sensual component.

A combination of sense and perception, concentration and selfsufficiency of poetic language, its capacity to design an imaginative world comprise the essence of iconic image. Thus, a key problem that appears in connection with the inclusion of the notion of image in the metaphor theory refers to the status of a sensual component, i.e. a non-verbal factor in a semantic theory.

The best explanation of iconic in the semantic theory of metaphor was given by M. Hester on the basis of the notion "to see as" that is realized in the process of reading and refers to a "mode of apprehension realization". In his opinion, "to see as" provides a real connection between a vehicle (a shell, an image) and a tenor (content, sense). Correspondingly, to interpret a metaphor means to set a range of meanings in which an image is taken as sense. "To see as" is an intuitive relation that combines an image and sense. A metaphor, which is based on the notion "to see as" defines a figurative function of poetic language, called by Hester "a picture of thinking"11.

In his turn a link between apprehension and perception Gaston Bachelard designated as "retentissement". In poetry a verbal meaning

${ }^{10}$ Рикёр П. Метафорический процесс как познание, воображение и ощущение / П. Рикер ; [пер. с анг., фр., нем., исп., польск. яз., общ. ред. Н. Д. Арутюновой и М. А. Журинской] // Теория метафоры : сборник. М. : Прогресс, 1990. С. 432.

${ }^{11}$ Hester M. B. An Analysis of the Meaning of Poetical Metaphor / M. B. Hester. L., 1964. P. 68. 
produces images that seem to be instaurated imprints of sensual experience. And if poetry is a fire, then images are brashwood that should be constantly supplied for imagination flight. Thus, "the unity of images melted by fire is stronger than the unity of ideas"12.

Early research of literary texts from the perspectives of cognitive linguistics proved the necessity of studying conceptual metaphoric systems as inseparable elements of author's individual style in poetry. The main focus is shifted to the idea that language of poetry relates to the spheres of conceptual metaphors functioning, as far as basic metaphoric concepts are integral parts of both common (universal) and individual (personal) conceptual domains.

The analysis of poetic texts enabled G. Lakoff and M. Turner to establish a set of basic metaphors, called specific-level metaphors, which function in poetry of different cultures and epochs. These metaphors structure the conceptual domains of such concepts as LIFE, DEATH and TIME. According to G. Lakoff and M. Turner, the specificity of poetic composition lies in the fact that basic metaphors undergo the process of the author's interpretation, resulting in the formation of novel metaphors. They distinguish three mechanisms of their creation: 1) various combinations on the basis of specific-level metaphors; 2) a metaphoric concept slots extension; 3) a different metaphoric concept slots filling ${ }^{13}$. O. P. Vorobyova considers these mechanisms to be extension, elaboration, combination and questioning. To illustrate them the scholar analyses V. Woolf's short story "The Mark on the Wall"14.

V. H. Nikonova designates novel metaphors as occasional metaphors and assumes them to be a conceptual basis of verbal poetic images, created by the author to model a conceptual space of a poem and produce an impact on a reader ${ }^{15}$. In her opinion, an image is one of the most important

${ }^{12}$ Башляр Г. Фрагменти Поетики Вогню / Густав Башляр ; [пер. 3 фр.]. Харків : Фоліо, 2004. С. 81.

${ }^{13}$ Lacoff G., Turner M. More than cool reason: a field guide to poetic metaphor / G. Lacoff, M. Turner. Chicago : University of Chicago Press, 1989. P. 52.

${ }^{14}$ Воробйова О. П. Когнітивна поетика : здобутки і перспективи / О. П. Воробйова // Вісник ХНУ ім. В. Н. Каразіна. Ювілейний збірник "200-річчя Харківської мовознавчої школи”. Харків : Константа, 2004. № 635.С. 18-22.

${ }^{15}$ Ніконова В. Г. Трагедійна картина світу в поетиці Шекспіра : монографія / Віра Григорівна Ніконова. Дніпропетровськ : Вид-во ДУЕП, 2007. С. 303. 
structures in the author's conceptual system that reveals how $\mathrm{h} / \mathrm{she}$ perceives, categorizes and interprets the reality.

\section{Metaphor and the principles of modeling a conceptual system}

As a unique cognitive mechanism metaphor imposes its peculiarities on structuring (or modeling) the conceptual system of the author.

Metaphor offers a personal perspective on the object, predetermining the way and the method of thinking about it. Images that implement a certain concept reflect a sustainable model that determines the direction of the concept development and its place in the structure of the interaction with other concepts. This conceptual model forms a channel through which a thought flows. The construction of a conceptual system is possible through the identification and description of this model or models. Thus, a metaphor and a conceptual system form an indissoluble unity. On the one hand, the analysis of metaphor mechanisms inevitably requires consideration of its functioning in the conceptual system of the author. On the other hand, it is possible to study the organization of the system through the metaphorical expressions. This raises the question of the reader's understanding of metaphors, used by the author in the text. Obviously, a poetic metaphor always contains some inaccessible meaning, correlating with the personal experiences of an author. Besides, a reader can put his/her individual meanings that are inseparable from their feelings and associations. This parallel outcome of the meanings predetermines the mystery of metaphor, its partial or complete unpredictability. An act of metaphor perception presupposes such a complex and multidimensional response from the conceptual system of the reader that would fully cover it. Creating and understanding metaphor is equally designed for involvement of both participants of the dialogue - the writer and the reader. When the reader is confronted with already mastered concepts, his/her goal is to actualize them in mind. This is the case of the so-called trite or linguistic metaphor.

The process of forming a concept in the reader's mind becomes more complicated when it comes to a poetic metaphor. This complication does 
not depend on the specifics of the mechanisms of perception of such metaphors, but on the peculiarities of the author's world vision.

Teresa Dobzhinskaya, while describing metaphor as a poetic means of conceptualization, argues that "the study of a linguistic world vision, i.e. modeling function embodied in the language of metaphors, should create the basis for the analysis of individual worldviews, created in the literary texts" $"$. Thus, it becomes obvious that the peculiarity of metaphor as an object of study consists in the reflection of the dynamics of interaction between conceptual and linguistic spheres. The author's individual world vision (view, image) determines the choice of expressive means. It follows that metaphor is bilateral essence that synthesizes two areas - linguistic and mental - in a single generating mechanism. This is how a new concept is born in the reader's mind. The novelty lies not in questioning or replacement of an already existing concept, but in its clarification or interpretation through another one.

The theory of conceptual metaphor proves that metaphor plays an important role in the formation of a linguistic world vision. When trying to interpret the language world vision, images of a particular concept, contained in metaphor, "pass" through the language material, creating separate metaphorical fields and forming the background for a new mode of thinking, which is based on cognitive processes of conceptualization. The choice of a certain image in metaphor is associated with the subjective intention, which expresses human knowledge and experience. This intention gives a particular understanding of the world and the system of images, connected with the creator's conceptual world vision.

An interesting metaphorical understanding of the linguistic picture of the world is given by Danka Siroka: "The linguistic picture of the world, seen as mental awareness of words from a linguistic, cultural, social and psychological point of view, could be metaphorically described as a broad avenue with a number of small trees, and each of them is beneficial to the

16 Добжинская Т. Мой интимный маленький мир и поэтические способы концептуализации: Метафора / Т. Добжинская // Слово в тексте и в словаре. Сб. ст. к семидесятилетию акад. Ю.Д. Анресяна. Москва : Языки русской культуры, 2000. C. 536 . 
avenue, because it represents a new incentive for making the atmosphere of the avenue complete" 17 .

Most researchers conclude that the linguistic world vision is a part of conceptual and contains information that supplements the content of the latter. Thus, a linguistic world vision as an integral part of a conceptual world vision performs its two main functions - designates the basic elements of the conceptual world vision and explicates it with the help of language means. The conceptual world vision is broader than linguistic one, since its formation involves all of the psychiatric activities ranging from feelings, perceptions and ideas to thinking and self-awareness: a human feels the world, contemplates, learns and reflects it, using different types of reasoning.

The linguistic world vision represents, in fact, the same construct as scientific, philosophical and others, necessary for investigating the processes associated with the formation of the world visions in consciousness. It acts as an integral universal model capable of serving as a template for experience structuring. The conceptual world vision is constantly "redrawn", while in language the perception of the world imprints for a long time. Thus, the conceptual and linguistic world visions are closely connected. Language, on the one hand, objectifies the elements of the conceptual world vision, and on the other, directs the process of its formation.

The emotional sphere proves to be an important integral part of a conceptual system. The entire aspects of human psychological activity take part in its formation. The image of world emerges in various acts of experiencing the world as a whole. The human consciousness is not only the awareness of the object in the process of perception, but it is experienced as something emotionally coloured. In emotions an epistemological opposition between objective and subjective fades away, thus the subject and the object are experienced as a unity ${ }^{18}$.

${ }^{17}$ Siroka D. A Linguistic Picture of the World and Expression of Emotions through the Prism of Expressive Lexis / D. Siroka // Journal of Education Culture and Society. 2013. № 2. P. 304.

18 Постовалова В. И. Картина мира в жизнедеятельности человека / В. И. Постовалова. М. : Наука, 1988. С. 20. 
In psycholinguistics knowledge and emotions are interpreted as interconnected components of a human affective and cognitive orientation. The primitive level of consciousness is represented by feelings, which are structured and organized by emotion. A human reaction on a stimulus is based on sensory information. On the level of sensitive perception the image is understood as feeling. This is the first stage of a concept creation, a stimulus to its further development and fixation in a conceptual system through the word. And this is a starting point for other cognitive functions. Thus, emotion experienced as a feeling motivates thinking. Besides, emotion also appears as a response on a definite mental image. It follows that a cognitive process can initially provoke emotions. Here we deal with two dimensional connections in which an image plays a crucial role. An image activates emotion, which, in its turn, stimulates a cognitive process ${ }^{19}$.

On the stage of its formation a metaphor is an image. Metaphor appears as an image that appeals to emotions. Therefore an image has a special intermediate status between verbal and nonverbal aspects of metaphorical expressions.

M. V. Nikitin defines an image as "a mode by which consciousness solves the problems of conceptualization ${ }^{20}$. An image defines the human capacity to relatively unanimous means of differentiating classes of objects. An image ties the notion with a sensitively perceived object and along with this it transforms concrete feelings into general abstract thinking forms. Thus, an image is a nucleus component of a concept structure, without which a concept cannot function as a discrete unit of thought and interact with other concepts. Metaphor also represents an instance of a conceptual interaction. It is frequently used to designate a new concept or enrich an old one by drawing an analogy between new entities. An image can serve as an activator of consciousness information state when one concept can provoke or implicate another concept. This seems to be a metaphor's modeling potential.

${ }^{19}$ Фрумкина Р. М. Психолингвистика / Р. М. Фрумкина. Москва : Академия. 2001. C. 45

${ }^{20}$ Никитин М. В. Основы когнитивной семантики / М. В. Никитин. СПб. : Изд-во РГПУ им. А. И. Герцена, 2003. С. 76. 
A writer has different figurative images while touching upon language. They are tightly linked by his/her world vision. An analogy in metaphor is not a mere search for similarities in objects, events or phenomena, but it directly refers to the author's cognitive, creative aspiration and worldview.

The specificity of a metaphoric interaction in an author's conceptual system proves to be the so-called "magnet poles", i.e. a certain orientation marks that define a choice of a certain image in a metaphor. Their totality comprises a number of common schemas, shaping a cycle of associative links between different concepts. These concepts are believed to be core elements of the author's mental lexicon, which actualizes in a text and forms verbal networks, defined by the author's individual picture of the world.

A verbal poetic image is defined as a linguistic and cognitive construct that incorporates pre-conceptual, conceptual and verbal angles, being the crossing point of different types of knowledge ${ }^{21}$. In their turn, verbal poetic images based on comparison are interpreted as text constructs that contain conceptual and verbal poetic text levels.

\section{LIFE and DEATH metaphors as a core of the author's conceptual system in romantic poetry}

As it has been already mentioned, the analysis of poetic texts enabled G. Lakoff and M. Turner to establish a set of basic metaphors that structure the conceptual domains of such concepts as LIFE, DEATH and TIME, which can be found in poetry of different cultures and epochs ${ }^{22}$.

Let us illustrate G. Byron's metaphors of LIFE and DEATH in romantic poetry. A basic metaphor LIFE IS A ROAD has a negative emotive connotation in Byron's poetry, actualizing the meaning of life hardships and obstacles. For instance, in the poem "On My Thirty-Three Birthday" a basic metaphor is elaborated through the mechanism of

21 Бєлєхова Л. І. Словесний поетичний образ в історико-типологічній перспективі : Лінгвокогнітивний аспект (на матеріалі американської поезії) / Л. І. Бєлєхова. К. : Вид. центр КНЛУ, 2002. С.146.

${ }^{22}$ Lacoff G., Turner M. More than cool reason: a field guide to poetic metaphor / G. Lacoff, M. Turner. Chicago : University of Chicago Press, 1989. P. 4. 
degradation: "Though Life's dull road, so dim and dirty, I have dragged to three-and-thirty. What have these years left to me? Nothing - except thirtythree." Thus, a metaphor is realized in a nominative metaphoric expression and represents a case of attributive mapping, illustrating one of the most frequent landscape concepts in English metaphoric picture of the world. A metaphoric attributive construction "'Life's dull road, so dim and dirty" is adequately connected with a metaphoric predicate "I have dragged". In this way the poet implicitly expresses a specific meaning of the road that he has gone, vividly presenting it as rough and difficult. The use of such attributes as "dull", "dim" and "dirty" extends the basic metaphor, causing the reconstruction of poetic metaphors LIFE IS A DULL ROAD, LIFE IS A DIM ROAD, LIFE IS A DIRTY ROAD.

In the poem "Darkness" Byron metaphorizes WATER and its properties for creating a depressing picture of darkness and hollowness. On the background of water a feeling of disaster is depicted with a powerful poetic mood: "The rivers, lakes and oceans all stood still, And nothing stirred within their silent depths; Ships sailorless lay rotting on the sea, And their masts fell down piecemeal: as they dropped They slept on the abyss without a surge - The waves were dead;"

A basic concept LIFE IS WATER is implicitly understood through the meaning of "still" water that is deprived of dynamics and movement, which in turn is interpreted as death. Thus, the image of still water is a symbol of DEATH that is realized in a poem through a mechanism of extension the associatively connected images: "the rivers, lakes and oceans all stood still", "the waves were dead", and "nothing stirred within their silent depths", "Ships sailorless lay rotting on the sea", "they slept ...without a surge". Correspondingly, an emotive background of water that does not move has a vivid negative connotation which is revealed due to various meanings of lexemes still, silent, sailorless, rotting, without a surge. It becomes obvious that a poetically elaborated image of still water aims at realizing a binary metaphor of DEATH by degradation of conceptual content of a source concept.

A poetic metaphor LIFE IS AN OCEAN is reconstructed in the poem "The Dream": "<..> she was his life, The ocean to the river of his 
thoughts, Which terminated all: upon a tone, A touch of hers, his blood would ebb and flow, And his cheek change tempestuously - his heart Unknowing of its cause of agony". Here again, a metaphor is realized implicitly through indirect meanings that are aimed at depicting romantic relationships of lyric heroes. The source concept LIFE serves the basis for creating a metaphoric picture by combining satellitative metaphoric meanings. The connotative meaning of the ocean as the biggest water container underlies a metaphoric mapping. In this way the poet presents the role of a loved woman in life with a strong emotional impact. An analogy between LIFE and OCEAN on the one hand, and THOUGHTS and RIVER on the other, is clearly drawn and similar to how rivers fill the ocean, the thoughts about a woman make sense in life of a romantic hero. This meaning is concentrated in the predicate "terminated" and is extended by a chain of associative images: her tone and touch made his blood ebb and flow. The lexeme "ebb" is used in the marine terminology to describe a water outflow, and indirectly it designates the meaning of dying away, when speaking about life. Thus, WATER and its properties are widely used by Byron to metaphorically represent LIFE.

In the poem "Stanzas To Augusta" binary metaphors LIFE IS LIGHT and DEATH IS DARKNESS are modified into a range of poetic metaphors through the mechanisms of restriction, degradation and combination. "Oh! blest be thine unbroken light! That watched me as a Seraph's eye, And stood between me and the night, For ever shining sweetly nigh. And when the cloud upon us came, Which strove to blacken o'er thy ray-Then purer spread it gentle flame, And dashed the darkness all away." The author regards LIGHT as life stamina capable of conquering DARKNESS and thus fighting DEATH. The poetic image is built on the usage of lexemes with opposing meanings, producing an effect of contrast and adding much to a destructing power of DARKNESS and life-affirming nature of LIGHT that forever shines "sweetly nigh" and stands "between me and the night". A constant struggle between two powers is metaphorically represented in an image of clouds, which "strove to blacken o'er thy ray". However, a poet believed that "gentle flame" "dashed the darkness all away". The actualization of LIGHT 
positive characteristics is done by using attributive lexemes sweetly, purer, gentle that contrast with the lexemes verbalizing DARKNESS: cloud, blacken, night. Metaphorically, death's coldness is night's coldness, since death is night ${ }^{23}$.

The opposition of LIFE and DEATH metaphors is the best realized in "Sun of the Sleepless", in which the images of powerless rays and a cold sun depict a picture of doomsday. Byron combines the depth of thought with an immense feeling of disaster. "Sun of the sleepless! melancholy star! Whose tearful beam glows tremulously far, That show'st the darkness thou canst not dispel, How like art thou to Joy remembered well! So gleams the past, the light of other days, Which shines, but warms not with its powerless rays: A night-beam Sorrow watcheth to behold, Distinct, but distant - clear but, oh how cold!' A basic metaphor LIFE IS THE SUN is realized implicitly through conceptual mechanisms of combination, extension and degradation of the content of a source concept, being expressed by lexemes that verbalize light and its attributes. "Sun of the sleepless!" is a genitive metaphoric construction that contains a complex compressed poetic image, being actualized by extension and combination of a range of metaphoric meanings. Lexemes that designate light properties of the sun occur through the whole poem space. However, their frequent occurrence seeks for creating an opposite effect by degradation the conceptual content of the source concept. The poet calls the sun a "melancholy star! Whose tearful beam glows tremulously far" for it is incapable to dispel the darkness with its "powerless rays". "It is the light of other days" implies the meaning of inevitable darkness that is going to rein. A personified Sorrow becomes the lord of universe and everything is shrouded by night and cold. The analysis done enables us to conclude that the SUN in Byron's conceptual system is tightly connected with the meanings of LIFE. However, the process of metaphors modification involves more the properties of light, warmth and energy. An image of disaster is built on the metaphor of SUN that shines, but does not warm, simultaneously realizing a binary metaphor of DEATH.

${ }^{23}$ Lacoff G., Turner M. More than cool reason: a field guide to poetic metaphor / G. Lacoff, M. Turner. Chicago : University of Chicago Press, 1989. P. 6. 
DEATH is one of the key concepts in E. Dickinson's poetry. However, its metaphors represent different images, which are never repeated. The most frequent proves to be a metaphor DEATH IS A DEPARTURE that undergoes various modifications, demonstrating the poetess's world vision. "Because I could not stop for Death - He kindly stopped for me - The Carriage held but just Ourselves - And Immortality". A poetic metaphor DEATH IS A COACHMAN is made through a conceptual mechanism of restriction and death personification (the usage of a pronoun $\mathrm{He}$ ). The image of "The Carriage held just Ourselves - and Immortality" implies the meaning of a departure with no return. And it is a natural way we perceive of death. As G. Lakoff and M. Turner fairly state that when we read "Because I could not stop for Death - " and understand that what the speaker could not stop are her purposeful activities, we can understand those purposes as destinations and her life as a journey to reach those destinations. The occurrence of the word "Death" in the line suggests the reading that what she declines to stop is her life's journey. The second line, "He kindly stopped for me", and the occurrence of "Carriage" in the third line make it clear that what is being talked about is a journey. Thus, LIFE IS A JOURNEY with a stopping point, and that stopping point is DEATH'S departure point. Consequently, DEATH IS A JOURNEY with a destination $^{24}$.

Like Byron in his poem "Darkness", Dickinson also metaphorically presents DEATH as STILLNESS in the poem "I heard a Fly buzz": "I heard a Fly buzz - when I died - The Stillness in the Room Was like the Stillness in the Air - Between the Heaves of Storm - ". A poetic image of DEATH is built on the meaning of absence of movement, dynamics, on the one hand, and sound - on the other. "A Fly that buzzes", i.e. makes noise, produces a contrast to almost the universal silence that makes everything still, motionless both "in the Room" and "in the Air".

This poem is often seen as a demonstration of Emily Dickinson's style and worldview. It is one of the most famous pieces of synesthesia in Emily Dickinson's poems. The metaphoric image of DEATH represents the

${ }^{24}$ Lacoff G., Turner M. More than cool reason: a field guide to poetic metaphor / G. Lacoff, M. Turner. Chicago : University of Chicago Press, 1989. P. 4 
fusion of color, sound and movement, weakly felt by dying person's senses. The uncertainty of the fly's darting motions parallels her state of mind. Flying between the light and her, it seems to both signal the moment of death and represent the world that she is leaving. The last two lines show the speaker's confusion of her eyes and the windows of the room - a psychologically acute observation because the windows' failure is the failure of her own eyes that she does not want to admit. She is both distancing fear and revealing her detachment from life $\mathrm{e}^{25}$.

Although the previous poem was written about a carriage ride of eternal death, Emily Dickinson's poem, "I heard a Fly buzz - when I died", is told by a woman who is still speaking and still hearing things upon her death. Because the dead woman can still speak, Dickinson feels that dying is continuous and incessant.

In E. Dickinson's poetry LIFE is conceived of in terms of bodily BONDAGE. The soul of a person leading the life is metaphorically a bound prisoner. Thus, LIFE can be said to imprison the soul in the body. The event of DEATH is metaphorically the event of being released from imprisonment. "Afraid? Of whom am I afraid? Not Death, for who is He? The porter of my father's lodge As much abasheth me..." . This example illustrates the image of DEATH that is metaphorically presented as an escape and a comfortable shutter for a soul. "My father's lodge" is home and the soul's final resting place and "the porter" who ushers you into that home is DEATH personified.

In the poem "I measure every Grief I meet" LIFE is understood in terms of a PAINFUL STATE: "I wonder if it hurts to live - And if They have to try - And whether - could They choose between - It would not be to die - ". A metaphorical predicate "it hurts to live" actualizes the meaning of physical state and a poetic metaphor is created through a conceptual mechanism of degradation as LIFE turns to be painful and full of sufferings.

In the poem "My life had stood - a Loaded Gun" depicts the poetess's metaphorical vision of afterlife. "My life had stood - a Loaded Gun - In

${ }^{25}$ Lundin R. Emily Dickinson and the Art of Belief / R. Lundin. Eerdmans Publishing Co., 2004. P. 56. 
Corners - till a Day The Owner passed - identified - and carried Me away". Again a meaning of departure is central in DEATH image. "And when at Night - Our good Day done - I guard My Master's Head". A LIFETIME IS A DAY metaphor intensifies the meaning of a life's short spin. On the contrary, DEATH IS A NIGHT metaphor implies the idea of birth-death circle, which is impossible to escape.

All of these varied metaphors of DEATH, however, do not truly contradict each other. Death is the ultimate unknowable, and so Dickinson circles around it, painting portraits of each of its many facets, as a way to come as close to knowing it as she can.

It has been assumed that there exist basic conceptual metaphors for understanding LIFE and DEATH that are part of our culture. The Dickinson's poem were chosen "to introduce the range of common, unconscious, automatic basic metaphors which are part of our cultural knowledge and which allow us to communicate with each other, whether in ordinary conversation or in poetry" 26 .

The analysis of conceptual metaphors and modes of their elaboration in romantic poetry makes it clear that LIFE and DEATH metaphors comprise the core of the writers' conceptual system. The most frequent conceptual mechanisms of poetic metaphors modification prove to be degradation, extension and combination. The poetic image is reconstructed in the process of interpretation and analysis of the conceptual content of the source concept, which is, however, predominately actualized in an inner structure of a text, i.e. implicitly.

The conceptual structure of LIFE and DEATH metaphors in G. Byron's and E. Dickinson's poetry is shown in Table 1 below.

The specificity of metaphoric interaction in the author's conceptual system is defined by the so-called "orientators" which determine a choice of a certain image in metaphor. The totality of them composes a number of common schemes that shape a circle of associative and sense-forming links between key concepts. These concepts are considered to be core elements of the author's mental lexicon. And being actualized in a text, they

${ }^{26}$ Lacoff G., Turner M. More than cool reason: a field guide to poetic metaphor / G. Lacoff, M. Turner. Chicago : University of Chicago Press, 1989. P. 15. 
constrain verbal networks, the system of which is conditioned by the author's individual picture of the world.

Table 1

\section{The conceptual structure of LIFE and DEATH metaphors in romantic poetry}

\begin{tabular}{|c|c|c|c|c|}
\hline \multirow{2}{*}{ 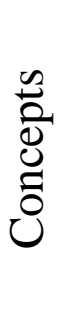 } & \multicolumn{2}{|c|}{$\begin{array}{l}\text { Conceptual metaphors } \\
\text { in Byron's poetry }\end{array}$} & \multicolumn{2}{|c|}{$\begin{array}{l}\text { Conceptual metaphors } \\
\text { in Dickinson's poetry }\end{array}$} \\
\hline & $\begin{array}{c}\text { Basic } \\
\text { conceptual } \\
\text { metaphors }\end{array}$ & $\begin{array}{c}\text { Poetic } \\
\text { conceptual } \\
\text { metaphors }\end{array}$ & $\begin{array}{c}\text { Basic } \\
\text { conceptual } \\
\text { metaphors }\end{array}$ & $\begin{array}{c}\text { Poetic } \\
\text { conceptual } \\
\text { metaphors }\end{array}$ \\
\hline 䑁 & $\begin{array}{l}\text { LIFE IS A } \\
\text { ROAD } \\
\text { LIFE IS } \\
\text { WATER } \\
\text { LIFE IS } \\
\text { MOVEMENT } \\
\text { LIFE IS LIGHT } \\
\text { LIFE IS THE } \\
\text { SUN }\end{array}$ & $\begin{array}{l}\text { LIFE IS A } \\
\text { DULL ROAD, } \\
\text { LIFE IS A DIM } \\
\text { ROAD, LIFE IS } \\
\text { A DIRTY } \\
\text { ROAD } \\
\text { LIFE IS AN } \\
\text { OCEAN } \\
\text { LIFE IS } \\
\text { WARMTH }\end{array}$ & $\begin{array}{l}\text { LIFE IS A } \\
\text { JOURNEY } \\
\text { LIFE IS A } \\
\text { BURDEN } \\
\text { LIFETIME IS A } \\
\text { DAY }\end{array}$ & $\begin{array}{l}\text { LIFE IS A } \\
\text { PAINFUL } \\
\text { STATE } \\
\text { LIFE IS A } \\
\text { BODILY } \\
\text { BONDAGE }\end{array}$ \\
\hline 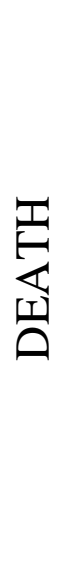 & $\begin{array}{l}\text { DEATH IS A } \\
\text { STOP } \\
\text { DEATH IS } \\
\text { NIGHT }\end{array}$ & $\begin{array}{l}\text { DEATH IS } \\
\text { STILL WATER } \\
\text { DEATH IS } \\
\text { DARKNESS } \\
\text { DEATH IS } \\
\text { COLD LIGHT } \\
\text { DEATH IS THE } \\
\text { RAYLESS SUN }\end{array}$ & $\begin{array}{l}\text { DEATH IS A } \\
\text { DEPARTURE } \\
\text { DEATH IS A } \\
\text { FINAL } \\
\text { DESTINATION } \\
\text { DEATH IS A } \\
\text { STOP } \\
\text { DEATH IS A } \\
\text { NIGHT }\end{array}$ & $\begin{array}{l}\text { DEATH IS A } \\
\text { COACHMAN } \\
\text { DEATH IS } \\
\text { HOME } \\
\text { DEATH IS AN } \\
\text { ESCAPE } \\
\text { FROM } \\
\text { SUFFERINGS } \\
\text { DEATH IS } \\
\text { STILLNESS }\end{array}$ \\
\hline
\end{tabular}

Being a model of concepts interaction, a metaphor forms an inseparable unity with the author's conceptual system. On the one hand, to study the mechanisms of metaphor creation and function it is necessary to consider the author's conceptual system. On the other hand, the research of metaphoric nomination can serve the basis for the study of this system organization and principles of its modeling. 


\section{CONCLUSIONS}

The research deals with the study of cognitive and psychological nature of metaphor and modes of its elaboration in romantic poetry. It is important to distinguish the way we conceive metaphorically from the way writers express such thoughts in their language. General conceptual metaphors are not the unique creation of individual poets, but are rather part of the way members of a culture have of conceptualizing their experience. Poets, as members of their cultures, naturally make use of these basic conceptual metaphors to communicate with their audience ${ }^{27}$. In addition to elaborating conventional metaphor, a poet goes beyond the normal use of conventional metaphor to point out and call into question the boundaries of our everyday metaphorical understandings of important concepts.

The attempt has been made to prove that any literary text reflects author's individual conceptual system, created by his/her artistic imagination and embodied with purposefully selected language means. Being a preferable language means in a dense poetic text, metaphor brings to the fore the importance of studying modes of its elaboration that reveal author's individual choice of image presentation. As far as a poetic metaphor is created and transmitted by an image, it undoubtedly appeals to emotions and text perception. Therefore, the image has a special status, "intermediate" between the verbal and nonverbal aspects of metaphorical expression. Metaphor is regarded as an illustration of rethinking of the linguistic forms. The choice of a certain image in metaphor is associated with the author's world vision and the system of stereotypical images. It has also been emphasized that poetry represents some artistic space in which metaphors undergo modifications and turn into complex poetic images.

In their turn, poetic metaphors have been viewed as an evidence of the individual mode of perception, organization and processing the artistic reality. Reflecting the dynamics of the interaction between conceptual and linguistic spheres, poetic metaphor is a unique tool for modeling the

${ }^{27}$ Lacoff G., Turner M. More than cool reason: a field guide to poetic metaphor / G. Lacoff, M. Turner. Chicago : University of Chicago Press, 1989. P. 9. 
individual world vision of the author. By means of a literary text, which is the result of the linguistic and cognitive activities, the author verbalizes his/her linguistic picture of the world. Thus, metaphor is fairly considered to be a core element in the author's individual conceptual system and cognitive style.

\section{SUMMARY}

The cognitive and psychological aspects of metaphor and its role in the author's conceptual system in poetry have been in the limelight of this research. The DEATH and LIFE metaphors have been studied from the perspectives of cognitive mechanisms of their creation and modification in romantic poetry. Besides metaphors have been regarded as a conceptual basis of verbal poetic images, created by the author to model a conceptual space of a poem and produce an impact on a reader.

\section{REFERENCES}

1. Арутюнова Н. Д. Метафора и дискурс / Н. Д. Арутюнова ; [пер. с анг., фр., нем., исп., польск. яз., общ. ред. Н. Д. Арутюновой и М. А. Журинской] // Теория метафоры : сборник. М. : Прогресс, 1990. C. 5-32.

2. Башляр Г. Фрагменти Поетики Вогню / Густав Башляр ; [пер. 3 фр.]. Харків : Фоліо, 2004. 143 с.

3. Бєлєхова Л. І. Словесний поетичний образ в історикотипологічній перспективі : Лінгвокогнітивний аспект (на матеріалі американської поезії) / Лариса Іванівна Бєлєхова. К. : Вид. центр КНЛУ, 2002. 368 с.

4. Воробйова О. П. Когнітивна поетика : здобутки і перспективи / О. П. Воробйова // Вісник ХНУ ім. В. Н. Каразіна. Ювілейний збірник “200-річчя Харківської мовознавчої школи”. Харків : Константа, 2004. № 635. С. 18-22.

5. Добжинская Т. Мой интимный маленький мир и поэтические способы концептуализации: Метафора / Т. Добжинская // Слово в тексте и в словаре. Сб. ст. к семидесятилетию акад. Ю. Д. Апресяна. Москва : Языки русской культуры, 2000. С. 529-537. 
6. Ніконова В. Г. Трагедійна картина світу в поетиці Шекспіра : монографія / В. Г. Ніконова. Дніпропетровськ : Вид-во ДУЕП, 2007. $364 \mathrm{c}$.

7. Никитин М. В. Основания когнитивной семантики / М. В. Никитин. СПб. : Изд-во РГПУ им. А. И. Герцена, 2003. 277 с.

8. Павличко С. Д. Байрон. Нарис життя і творчості / Соломія Дмитрівна Павличко // Зарубіжна література : Дослідження та критичні статті. К. : Вид-во Соломії Павличко “Основи”, 2001. C. $153-270$.

9. Постовалова В. И. Картина мира в жизнедеятельности человека / В. И. Постовалова. М. : Наука, 1988. С. 8-69.

10. Рикёр П. Метафорический процесс как познание, воображение и ощущение / П. Рикер ; [пер. с анг., фр., нем., исп., польск. яз., общ. ред. Н. Д. Арутюновой и М. А. Журинской] // Теория метафоры : сборник. М. : Прогресс, 1990. С. 416-434.

11. Фрумкина Р. М. Психолингвистика / Р. М. Фрумкина. Москва : Академия. 2001. 320 с.

12. Byron G. Selections From Byron. Lyrical Verse / G. Byron. Moscow: Progress Publishers, 1979. 520 p.

13. Dickinson E. The Selected Poems by Emily Dickinson / E. Dickinson. Hertfordshire : Wordsworth Editions Ltd, 1994. 214 p.

14. Freeman M. Poetry and the Scope of Metaphor : Toward a Cognitive Theory of Literature / M. Freeman // Metaphor and Metonymy at the Crossroad: A Cognitive Perspective / Ed. Barcelona A. Berlin ; N.Y. : Mouton de Gruyter, 2000. P. 253-283.

15. Freeman M. The Body in the World: A Cognitive Approach to the Shape of a Poetic Text / M. Freeman // Cognitive Stylistics : Language and Cognition in Text Analysis / Ed. by E.Semino, J.V. Culpeper. Amsterdam ; Philadelphia : John Benjamin's Publishing House, 2002. P. 23-48.

16. Gibbs R. W. The Poetics of Mind : Figurative Thought, Language and Understanding / R. W. Gibbs. Cambridge: Cambridge University Press, 1999. 527 p.

17. Hester M. B. An Analysis of the Meaning of Poetical Metaphor / M. B. Hester. L., 1964. 316 p. 
18. Lacoff G., Johnson M. Metaphors We Live By / G. Lacoff, M. Johnson. Chicago : The University of Chicago Press, 1980. 240 p.

19. Lacoff G., Turner M. More than cool reason: a field guide to poetic metaphor / G. Lacoff, M. Turner. Chicago : University of Chicago Press, $1989.230 \mathrm{p}$.

20. Lundin R. Emily Dickinson and the Art of Belief / R. Lundin. Eerdmans Publishing Co., 2004. 348 p.

21. Siroka D. A Linguistic Picture of the World and Expression of Emotions through the Prism of Expressive Lexis / D. Siroka // Journal of Education Culture and Society. 2013. № 2. P. 297-308.

22. Stockwell P. Cognitive Poetics: An Introduction / P. Stockwell. L.; N.Y. : Routledge Taylor \& Francis Group, 2002. 189 p.

23. Tsur R. Toward a Theory of Cognitive Poetics / R. Tsur. Amsterdam: Elsevier Science Publishers, 1992. 214 p.

\section{Information about the author:} Chendey N. V.,

Candidate of Philological Sciences in Comparative Linguistics, Associate Professor at the Department of English Philology Uzhhorod National University 14, office 539, Universytetska str., 88000, Uzhhorod, Zakarpattia region 